\title{
Monitoring and evaluating FGM/C abandonment programs
}

Jacinta Muteshi-Strachan

Population Council

Carolyne Njue

Population Council

Follow this and additional works at: https://knowledgecommons.popcouncil.org/departments_sbsr-rh

Part of the Demography, Population, and Ecology Commons, Family, Life Course, and Society Commons, International Public Health Commons, Maternal and Child Health Commons, Sociology of Culture Commons, and the Women's Health Commons How does access to this work benefit you? Let us know!

\section{Recommended Citation}

Muteshi-Strachan, Jacinta and Carolyne Njue. 2016. "Monitoring and evaluating FGM/C abandonment programs," presentation at the International Conference to End FGM, Geneva, 10-11 May. Nairobi: Population Council. 


\section{MONITORING AND}

EVALUATING FGM/C

ABANDONMENT PROGRAMS

Jacinta Muteshi and Carolyne Njue, Population Council

Inter-African Committee (IAC)

International Conference to end FGM

Geneva, Switzerland: 10-11 May, 2016 


\section{Background}

- Lack quality M\&E given:

- limited management information systems of FGM/C interventions

- Fragmented documentation of feasible \& effective policies and programs

- Need to improve national and global understanding of program implementation

- Relevant indictors

- Measurement and evaluation for documenting and reporting on $\mathrm{FGM} / \mathrm{C}$ activities 


\section{So... why should we undertake monitoring and evaluation?}

- Monitoring

To assess the process and progress of program implementation

- Evaluation

To assess the effect or impact of a program 


\section{Role of monitoring in FGM/C}

projects

- Did a program do what it was expected to do?

- Routine documentation and reporting of program activities and products to:

o Ensure that program activities are implemented as planned

o Identify problems as they arise so that they can be addressed

- Make sure resources are being used within budget (and for target population) 


\section{Role of evaluation in FGM/C projects}

- Evaluations can be useful for both finetuning innovative programs and for assessing impact of established programs

- Evaluation addresses the following questions:

- Were the program activities carried out as planned?

- What outcomes are observed?

- Does the program achieve the types of changes proposed in its objectives? How much change occurred?

- To what extent is the program responsible for the observed changes? Can improved outcomes be attributed to program efforts?

- Did the target population benefit from program and at what cost? 


\section{Challenges associated with M\&E}

- Hard to separate contribution of multiple strategies

- Lack of investment in rigorous evaluation

- limited evidence of effectiveness

- Non-standardized definitions and indicators

- Enhancing comparability of data

- Climate of urgency around results but behavior change is long-term

- Sensitive nature of the information

- Changing nature hard to measure and interpret

- Ethical and methodological issues 


\section{Evaluation issues to consider}

1. Impact on who?

- Participants in project activities

- Those influenced by project activities

- Those more indirectly influenced

2. Measuring impact - which indicators and validity?

- Statistical evidence for changes in FGM/C behaviors and prevalence

- Use of DHS / MICS data?

- Surveys of sample populations 


\section{Evaluation issues to consider}

3. Other influences on these changes?

- Use „experimental" evaluation design to control for other influences (include control /comparison group)

- Identify and document other anti-FGM/C activities within and near project sites

- Review history of anti-FGM/C activities in project sites

\section{Measuring unplanned impacts?}

- Fully understand how interventions can influence peoples lives beyond FGM/C

- Ask project staff to document all events as they occur

- Include qualitative research during endline to assess retrospectively how and why these changes happened

- Report these outcomes with other results, whether positive or negative 


\section{Evaluation issues to consider}

\section{Sampling for evaluations}

- Use an appropriate sampling plan.....

- For describing prevalence (e.g. baseline)

- For assessing impact of an intervention

- Sample separately for each sub-group assessed

- Use random not purposive sampling if possible

\section{Ethical considerations}

- Beneficence: maximise potential benefits for individuals and society

- Non-malfeasance: minimize any potential harms to individuals and society

- Respect for autonomy: respect rights of individuals and groups to make decisions for themselves, and protect persons with diminished autonomy (e.g. children)

- Justice: treat all subjects equally 
Thank you 